\title{
Development and evaluation of sustained release losartan potassium matrix tablet using kollidon SR as release retardant
}

\author{
Md. Shahid Sarwar, Mohammad Salim Hossain*
}

Department of Pharmacy, Noakhali Science and Technology University, Sonapur, Bangladesh

\begin{abstract}
The present study was undertaken to develop sustained release (SR) matrix tablets of losartan potassium, an angiotensin-II antagonist for the treatment of hypertension. The tablets were prepared by direct compression method, along with Kollidon SR as release retardant polymer. The amount of losartan potassium remains fixed $(100 \mathrm{mg}$ ) for all the three formulations whereas the amounts of Kollidon SR were $250 \mathrm{mg}, 225 \mathrm{mg}$, and $200 \mathrm{mg}$ for F-1, F-2, and F-3 respectively. The evaluation involves three stages: the micromeritic properties evaluation of granules, physical property studies of tablets, and in-vitro release kinetics studies. The USP apparatus type II was selected to perform the dissolution test, and the dissolution medium was $900 \mathrm{~mL}$ phosphate buffer $\mathrm{pH}$ 6.8. The test was carried out at $75 \mathrm{rpm}$, and the temperature was maintained at $37^{\circ} \mathrm{C} \pm 0.5^{\circ} \mathrm{C}$. The release kinetics was analyzed using several kinetics models. Higher polymeric content in the matrix decreased the release rate of drug. At lower polymeric level, the rate and extent of drug release were enhanced. All the formulations followed Higuchi release kinetics where the Regression co-efficient $\left(\mathrm{R}^{2}\right)$ values are $0.958,0.944$, and 0.920 for F-1, F-2, and F-3 respectively, and they exhibited diffusion dominated drug release. Statistically significant $(\mathrm{P}<0.05)$ differences were found among the drug release profile from different level of polymeric matrices. The release mechanism changed from non-fickian ( $\mathrm{n}=0.489$ for $\mathrm{F}-1)$ to fickian ( $\mathrm{n}=0.439$ and 0.429 for $\mathrm{F}-2$, and F-3 respectively) as a function of decreasing the polymer concentration. The Mean Dissolution Time (MDT) values were increased with the increase in polymer concentration.
\end{abstract}

Uniterms: Losartan potassium/sustained release/development. Losartan potassium/sustained release/ evaluation. Tablets/direct compression. Kollidon SR./use/release retardant.

O presente estudo foi realizado para desenvolver (SR) matriz de comprimidos de liberação sustentada de losartana, um antagonista da angiotensina II, para o tratamento da hipertensão arterial. Os comprimidos foram preparados pelo método de compressão direta com Kollidon SR como polímero de liberação lenta. A quantidade de losartana potássica permanece fixa $(100 \mathrm{mg})$ para todas as três formulações enquanto que as quantidades de Kollidon SR foram de $250 \mathrm{mg}, 225 \mathrm{mg}$ e $200 \mathrm{mg}$ para F-1, F-2 e F-3, respectivamente. A avaliação envolve três etapas- propriedades micromeríticas dos grânulos, estudo das propriedades físicas dos comprimidos e estudos de cinética de liberação in vitro.. Selecionoou-se o aparelho USP tipo II para realizar o teste de dissolução em meio com $900 \mathrm{~mL}$ de tampão fosfato $\mathrm{pH} 6,8$. O teste foi realizado em $75 \mathrm{rpm}$ e a temperatura foi mantida a $37{ }^{\circ} \mathrm{C} \pm 0.5^{\circ} \mathrm{C}$. Analisou-se a cinética de liberação utilizando-se vários modelos cinéticos. Conteúdo mais alto de polímero na matriz reduziu a taxa de liberação do fármaco. Em níveis mais baixos de polímero, a taxa e a extensão de liberação do fármaco foram aumentados. Todas as formulações seguiram a cinética de liberação de Higuchi, em que os valores do coeficiente de regressão (R2) foram 0,958, 0,944 e 0,920 para F-1, F-2 e F-3, respectivamente, e elas apresentaram liberação do fármaco dominada pela difusão. Encontraramse diferenças estatisticamente significativas $(\mathrm{P}<0,05)$ entre os perfis de liberação do fármaco com diferentes níveis de matrizes poliméricas. O mecanismo de liberação mudou de não-fickiano(n=0,489 para F-1) para fickiano(n=0,439 e 0,429 para F-2 e F-3, respectivamente) em função da diminuição

\footnotetext{
*Correspondence: M. S. Hossain. Department of Pharmacy, Noakhali Science and Technology University, Sonapur, Noakhali-3802, Bangladesh. E-mail: pharmasalim@yahoo.com
} 
da concentração de polímero. Os valores do Tempo de Dissolução Média (TDM) aumentaram com o aumento da concentração polímero.

Unitermos: Losartana/liberação sustentada/desenvolvimento. Losartana/liberação sustentada/avaliação. Comprimidos/compressão direta. Kollidon SR./uso/retardador de liberação.

\section{INTRODUCTION}

The objective of an ideal drug delivery system is to deliver adequate amount of drug for an extended period for its optimum therapeutic activity. Most drugs are inherently not long-lasting in the body, and require multiple daily dosing to achieve the desired blood concentration to produce therapeutic activity. To overcome such problems greater attention has been focused on sustained release drug delivery system (Chien, 1992).

Losartan potassium is an orally active angiotensin-II receptor antagonist used in the treatment of hypertension due to mainly blockade of $\mathrm{AT}_{1}$ receptor. It is freely soluble in water, slightly soluble in acetonitrile, and soluble in isopropyl alcohol. It is readily absorbed from the gastrointestinal tract with oral bioavailability of about 33 per cent and a plasma elimination half-life ranging from 1.5 to 2.5 hours. Administration of losartan potassium in a sustained release dosage form with dual characteristics, that is, burst release, followed by an extended release over 8 hours would be more desirable; as these characteristics would allow a rapid onset followed by protracted anti-hypertensive effect by maintaining the plasma concentration of the drug. Previously, several studies were conducted on losartan potassium by using various hydrophilic and hydrophobic polymers for their in-vitro evaluation (Chithaluru et al., 2011; Shanmugam et al., 2011).

The objective of the present investigation were to prepare sustained release matrix tablets of losartan Potassium by using Kollidon SR at three different concentrations, and to compare the in-vitro characteristics (weight variation, thickness and diameter, hardness, friability, drug content, release kinetics, etc.) of the developed matrix tablets. Kollidon SR is polyvinyl acetate and povidone based matrix-retarding agent. Polyvinyl acetate is insoluble in water. The povidone content is gradually leached out after introduction into water. Kollidon SR is completely soluble in N-methylpyrrolididone. It is particularly suitable for the manufacture of $\mathrm{pH}$ independent sustained release matrix tablets. Polyvinyl acetate is a plastic material that produces a coherent matrix even under low compression forces. When the tablets are introduced into gastric or intestinal fluid, the water-soluble povidone is leached out to form pores through which the active ingredient slowly diffuse outwards. Kollidon SR contains no ionic groups and is, therefore, inert to the drug substance (Reza, Quadir, Haider, 2003).

\section{MATERIAL AND METHODS}

\section{Material}

Losartan Potassium was kindly supplied by Globe Pharmaceuticals Limited, Noakhali, Bangladesh, as a gift sample. Kollidon SR was procured from BASF, Dhaka, Bangladesh Limited. Potassium di-hydrogen phosphate (Merck, Darmstadt, Germany), and sodium hydroxide (Merck, Darmstadt, Germany) were used as dissolution medium. Magnesium stearate and lactose were obtained from Novo Healthcare Limited, Dhaka, Bangladesh. Solvents and all other chemicals were of analytical grade.

\section{Methods}

\section{Preparation of matrix tablet}

Various methods are available for producing sustained release Losartan Potassium tablet preparation. In our experiment, direct compression technique was followed to prepare sustained release Losartan Potassium matrix tablet from the formulations mentioned in Table I.

TABLE I - Proposed formulations for sustained release losartan potassium matrix tablet

\begin{tabular}{lccc}
\multirow{2}{*}{ Ingredients } & \multicolumn{3}{c}{ Amount $(\mathrm{mg})$} \\
\cline { 2 - 4 } & F-1 & F-2 & F-3 \\
\hline Losartan Potassium & 100 & 100 & 100 \\
Kollidon SR & 250 & 225 & 200 \\
Lactose & 0 & 25 & 50 \\
Magnesium stearate & 3 & 3 & 3 \\
\hline Total & 353 & 353 & 353
\end{tabular}

The active ingredient (losartan potassium), release retardant (Kollidon SR), filler (lactose), and lubricant (magnesium stearate) were blended together by dry mixing. The dried granules were then sized through 40-mesh sieve. Finally, the granules were weighed to adjust the 
final weight of individual tablet considering its loss during operational handling. Then, the granules were made into tablets by direct compression at fixed compression force ( 5 ton) for specific period of time ( 2 minutes) by using hydraulic press (PIKE Technologies, India; Model: M-15) fitted with $13 \mathrm{~mm}$ dies.

\section{Micromeritic properties of granules}

- Bulk density

LBD (loose bulk density) and TBD (tapped bulk density) were determined by $5 \mathrm{~g}$ of powder from each formula-previously lightly shaken to break any agglomerates formed; and was placed into a $10 \mathrm{ml}$ measuring cylinder. After the initial volume was observed, the cylinder was allowed to fall under its own weight onto a hard surface from a height of $2.5 \mathrm{~cm}$ at 2 -second intervals. The reading of tapping was continued until no further change in volume was noted. LBD and TBD were determined by using following equations (Shah, Rampradhan, 1997):

LBD = Weight of the powder (W)/volume of the packing (V)

TBD $=$ Weight of the powder/Tapping volume of the packing

\section{- Carr's index}

The Carr's Index (CI) is an indication of the compressibility of a powder. It is calculated by the formula:

$$
\mathrm{CI}=\{(\mathrm{BD}-\mathrm{TD}) / \mathrm{BD}\} \times 100
$$

where, $\mathrm{BD}$ is the freely settled bulk density of the powder, and TD is the tapped bulk density of the powder (Rawlins, 1977).

\section{- Hausner's ratio}

The Hausner's ratio is a number that is correlated to the flowability of powder or granular material. It is calculated by:

$$
\mathrm{H}=\mathrm{BD} / \mathrm{TD}
$$

where, BD is the freely settled bulk density of the powder, and TD is the tapped bulk density of the powder (Grey, Beddow, 1969; Li, 2004; Conesa, 2004; Rough, Wilson, York, 2005).

\section{- Angle of repose}

The angle of repose of granules was determined by the funnel method. The accurately weighed granules were taken in a funnel. The height of the funnel was adjusted in such a way that the tip of the funnel just touched the apex of the heap of the granules. The granules were allowed to flow through the funnel freely onto the surface. The diameter of the powder cone was measured, and angle of repose was calculated using (Botz et al., 2003):

\section{Angle of repose $\theta=\tan ^{-1}(\mathrm{~h} / \mathrm{r})$}

where, ' $h$ ' is height of the powder cone, and ' $r$ ' is the radius of the powder cone.

\section{Physical parameters and drug content \\ - Weight variation}

For weight variation test, the weights of 10 tablets (Electronic balance AR2140, India) of each batch were taken individually, and calculated the average weight of 10 tablets of each batch. Then the percentage of weight variation was determined of each tablet by using (Rashid et al., 2009):

$\%$ Weight variation $=\{($ Average weight - Individual weight)/Average weight $\} \times 100$

- $\quad$ Thickness and diameter

The thickness and diameter of the tablets of all of the three formulations were determined with digital calipers (Range: 0-150 $\mathrm{mm}$ ).

\section{- Hardness}

Tablet hardness was determined with tablet hardness tester EH-OIP Electrolab, India (Kaushik, Dureja, Saini, 2004).

\section{- $\quad$ Friability}

The friability of the tablets was measured in a Roche friabilator (EF2 Electrolab, India). Tablets of a known weight $\left(\mathrm{W}_{1}\right)$ were de-dusted in a drum for a fixed time ( $25 \mathrm{rpm}$ for 4 minutes), and weighed $\left(\mathrm{W}_{2}\right)$ again. The weight loss should not be more than 1 per cent (Reddy et al., 2011).

$$
\text { Friability }=\left\{\left(\mathrm{W}_{1}-\mathrm{W}_{2}\right) / \mathrm{W}_{1}\right\} \times 100
$$

\section{- $\quad$ Drug content}

10 tablets were weighed and powdered; then, $176.5 \mathrm{mg}$ tablet powder (equivalent to $100 \mathrm{mg}$ ) was dissolved in buffer solution and made the volume up to $100 \mathrm{~mL}$. The solution was diluted 100 times, and absorbance was measured at $205 \mathrm{~nm}$ by using SHIMADZU UV-1800 spectrophotometer, Japan; and drug content was determined (Mansoor, Sharma, Dhakal, 2007).

\section{In vitro release studies}

\section{- Dissolution study procedure}

The in-vitro dissolution studies were performed using USP type-II dissolution apparatus (Rotating Peddle method) at $75 \mathrm{rpm}$. The dissolution medium consisted of potassium di-hydrogen phosphate buffer of $\mathrm{pH} 6.8$ up to $900 \mathrm{~mL}$, maintained at $37^{\circ} \mathrm{C} \pm 0.5^{\circ} \mathrm{C}$; where the tablets were completely in sink condition in the dissolution vessel. 
An aliquot (5 ml) was withdrawn at specific time intervals, which replaced by equivalent amount of buffer solution. The drug content was determined by UV-visible spectrophotometer (SHIMADZU UV-1800 spectrophotometer) at $205 \mathrm{~nm}$. The release studies were conducted in triplicate.

- $\quad$ Drug release kinetics

To analyze the mechanism of drug release from the matrix tablets, the release data were fitted to the following equations:

Zero-order equation: (Cooper and Gunn, 1986) $Q=\mathrm{k}_{0} \mathrm{t}$ where, $\mathrm{Q}$ is the amount of drug released at time $\mathrm{t}$, and $\mathrm{k}_{0}$ is the release rate.

First-order equation (Hadjiioannou, Christian, Koupparis, 1993):

$$
\log Q=\log Q_{0}-k_{1} t / 2.303
$$

where, $\mathrm{Q}$ is the amount of drug un-dissolved at time, $\mathrm{Q}_{0}$ is drug concentration at $\mathrm{t}=0$ and $\mathrm{k}_{1}$ is the release rate constant.

Higuchi's equation (Higuchi, 1963);

$$
\mathrm{Q}=\mathrm{k}_{2} \mathrm{t}^{1 / 2}
$$

where, $\mathrm{Q}$ is the percent of drug release at time $t$, and $\mathrm{k}_{2}$ is the diffusion rate constant.

Hixson-Crowell equation:

$$
\mathrm{Q}_{\mathrm{o}}{ }^{1 / 3}-\mathrm{Q}_{\mathrm{t}}{ }^{1 / 3}=\mathrm{K}_{\mathrm{o}} \mathrm{t}
$$

where, $Q_{t}$ is the initial amount of drug, $Q_{o}$ is cumulative amount of drug release at time $\mathrm{t}, \mathrm{K}_{\mathrm{o}}$ is Hixson-Crowell release constant and $t$ is time in hours.

Korsmeyer-Peppas equation (Korsmeyer et al., 1983):

$$
\log \left(M_{t} / M_{f}\right)=\log k+n \log t
$$

where, $M_{t}$ is the amount of drug release at time $t ; M_{f}$ is the amount of drug release after infinite time; $\mathrm{k}$ is a release rate constant incorporating structural and geometric characteristics of the tablet; and $\mathrm{n}$ is the diffusional exponent indicative of the mechanism of drug release.

To clarify the diffusion exponent (n) for different batches of matrix tablet, the log value of percentage drug released was plotted against log time for each batch. A value of $\mathrm{n} \leq 0.45$ indicates Fickian (case I) release; $>0.45$ but $<0.89$ for non-Fickian (anomalous) release; and $>0.89$ indicates super case II type of release. Case II generally refers to the erosion of the polymeric chain, and anomalous transport (Non-Fickian) refers to a combination of both diffusion and erosion-controlled drug release (Shato et al., 1997). Mean dissolution time (MDT) was calculated from dissolution data using the equation: (Mockel, Lippold, 1993)

$$
\operatorname{MDT}=(\mathrm{n} / \mathrm{n}+1) \mathrm{k}^{-1 / \mathrm{n}}
$$

where, $\mathrm{n}=$ diffusion exponent and $\mathrm{k}=$ release rate constant.

\section{RESULTS AND DISCUSSION}

The Micromeritic properties of granules are indicated in Table II. The results of bulk densities were $0.522,0.459$, and $0.454 \mathrm{~g} / \mathrm{mL}$ and the results of tapped bulk densities were $0.669,0.677$, and $0.708 \mathrm{~g} / \mathrm{mL}$ for F-1, F-2, and F-3 respectively. The bulk densities of granules of the proposed formulation F-1 were quite higher than that of other granules. This may be due to the presence of more fine granules (Nellore et al., 1998). The Hausner's Ratio for F-1, F-2, and F-3 were 1.34, 1.49, and 1.54 respectively. A Hausner's Ratio greater than 1.25 is considered an indication of poor flowability (Li, 2004). The angle of repose for F-1, F-2, and F-3 were $50^{\circ}, 48.7^{\circ}$, and $45.6^{\circ}$ respectively. The results of angle of repose $(>30)$ indicate unsatisfactory flow properties of granules (Rashid et al., 2009). A Carr's Index greater than 25 is considered an indication of poor flowability, and below 15 is of good flowability (Patel, Baria, 2009).

The mechanical properties of the Losartan Potassium tablets were improved (increased hardness and reduced friability) as the polymer concentration were increased. The produced tablets had thickness $(n=3)$ about $3 \pm 0.01$ $\mathrm{mm}$, and diameter $(\mathrm{n}=3)$ of about $13 \mathrm{~mm}$. Therefore, the polymer and other additives had no effect on the dimensions (thickness and diameter) of the Losartan Potassium matrix tablet, if the total weight is same, and the die and punch size is fixed. The weight variation $(n=10)$ test of the tablet meet the USP specification as indicated in Table II.

To establish the sink condition, we did not carry out the experiment directly, but in some reports (Bonfilio et al., 2010) have stated that the drug does not possess sufficient solubility in $0.1 \mathrm{~N}$ hydrochloric acid, whereas, it shows satisfactory solubility in phosphate buffer. In some reports (Bonfilio et al., 2010), it has been stated that the use of water as a dissolution medium is discouraged because test condition such as $\mathrm{pH}$ and surface tension can vary depending on water source, and may change during the dissolution test itself. For this reason, the phosphate buffer pH 6.8 was chosen as dissolution medium.

The calibration curve of analytical method exhibited excellent linearity $\left(\mathrm{R}^{2}=0.996\right)$ within the range of $1 \mu \mathrm{g} / \mathrm{mL}$ to $10 \mu \mathrm{g} / \mathrm{mL}$. For the UV spectroscopic method, the relative standard deviation (RSD) values for intraday system and method precision were 0.25 and 1.04 per cent, respectively. The specificity study indicated that no interference from the matrix and excipients was found in the placebo of the tablets. The sample was found to be stable at $25^{\circ} \mathrm{C}$ for $24 \mathrm{~h}$ and the overall RSD percentage was found to be 0.99 .

The drug content $(n=3)$ of the formulated tablet among different batches ranged from $99.7 \pm 1.2 \%$ to 
TABLE II- Micromeritic properties of granules and physical parameters of tablets

\begin{tabular}{lccc}
\hline Code & F-1 & F-2 & F-3 \\
\hline Bulk Density $(\mathrm{g} / \mathrm{mL})$ & 0.522 & 0.459 & 0.454 \\
Tap density $(\mathrm{g} / \mathrm{mL})$ & 0.669 & 0.677 & 0.708 \\
Carr's Index (\%) & 21.99 & 32.07 & 35.89 \\
Hausner's ratio & 1.28 & 1.49 & 1.54 \\
Angle of repose & $50^{\circ}$ & $48.7^{\circ}$ & $45.6^{\circ}$ \\
Average Weight ${ }^{*} \pm \mathrm{SEM}$ & $355.88 \pm 1.16$ & $353.78 \pm 0.68$ & $352.59 \pm 0.35$ \\
Thickness $(\mathrm{mm})^{* *} \pm \mathrm{SEM}$ & $3 \pm 0.01$ & $3.01 \pm 0.01$ & $3 \pm 0.01$ \\
Diameter $(\mathrm{mm})^{* *} \pm \mathrm{SEM}$ & $13 \pm 0$ & $13 \pm 0$ & $13 \pm 0$ \\
Hardness $(\mathrm{Kf})^{* *} \pm \mathrm{SEM}$ & $26.37 \pm 0.01$ & $22.82 \pm 0.17$ & $20.34 \pm 0.29$ \\
Friability $(\%)^{* *} \pm \mathrm{SEM}$ & $0.02 \pm 0.00$ & $0.04 \pm 0.01$ & $0.05 \pm 0.01$ \\
Drug content $(\%)^{* *} \pm \mathrm{SEM}$ & $99.7 \pm 1.2$ & $101.33 \pm 0.8$ & $102.5 \pm 1.3$ \\
\hline
\end{tabular}

$*(\mathrm{n}=10)$ and $* *(\mathrm{n}=3)$

$102.5 \pm 1.3 \%$ which meet USP specification $(100 \pm 5 \%)$. It was noticed that Kollidon SR has a unique character of maintaining tablets geometric shape (Sakr, Alanazi, 2011). This is one of the most common reasons for choosing the Kollidon SR as release retardant polymer as compared to all others hydrophobic polymer.

To know the mechanism of drug release from these formulations, the data were treated according to zero order (cumulative amount of drug released vs time), first-order (log cumulative percentage of drug remaining vs time), Higuchi's (cumulative percentage of drug released vs square root of time), Korsmeyer-Peppas (log cumulative percentage of drug released vs log time), and HixsonCrowell (cubic root of percent drug release vs time) pattern for kinetics of drug release during dissolution process (Reddy, Mutalik, 2003).

As clearly indicated in Table III, the formulations did not follow a zero-order release pattern (Figure 1) where the regression values are $0.808,0.782$, and 0.753 for $\mathrm{F}-1$, F-2, and F-3 respectively. When the data were plotted according to the first-order equation, the tablets showed a first order release, with regression value of $0.898,0.918$, and 0.911. The formulations showed to be best expressed by Higuchi's equation, as the plots showed high linearity with regression value of $0.958,0.944,0.920$ for Kollidon $\mathrm{SR}$, indicating that the drug releases follow the Higuchi release kinetics (Figure 2), and diffusion is the dominating drug release mechanism. This finding is similar to that of previously investigated work (Reza, Quadir, Haider, 2003; Shanmugam et al., 2011).

The dissolution data was also fitted to the wellknown exponential equation (Korsmeyer-Peppas equation), which is often used to describe the drug release behavior from polymeric systems. As indicated in the Table III, F-1 exhibited non-fickian type drug release, whereas, F-2 and F-3 exhibited fickian-type drug release from the tablet matrix. The percentage of drug release differs significantly at $\mathrm{P}<0.05$ from different amount of polymer matrices.

MDT values are used to characterize drug release rate from a dosage form and release retarding efficiency of the polymer. MDT value is higher for F-1 and lower for F-3 as shown in Table IV. Moreover, we calculated the $\mathrm{t}_{75 \%}$ values for all batches, and the data showed marked

TABLE III - In-vitro drug release kinetics for proposed formulations of Losartan Potassium sustained release matrix tablet

\begin{tabular}{lcccccccc}
\hline & \multicolumn{4}{c}{ Regression co-efficient $\left(\mathrm{R}^{2}\right)$ value } & & $\begin{array}{c}\text { Release rate } \\
\text { constant }(\mathrm{k})\end{array}$ & $\begin{array}{c}\text { Diffusion } \\
\text { exponent }(\mathrm{n})\end{array}$ \\
\cline { 2 - 9 } Code & Zero order & $1^{\text {st }}$ order & Higuchi & $\begin{array}{c}\text { Hixson- } \\
\text { Crowell }\end{array}$ & $\begin{array}{c}\text { Korsmeyer- } \\
\text { Peppas }\end{array}$ & Higuchi & $\begin{array}{c}\text { Korsmeyer- } \\
\text { Peppas }\end{array}$ \\
\hline F-1 & 0.808 & 0.898 & 0.958 & 0.466 & 0.946 & 0.316 & 0.489 & Non-Fickian \\
F-2 & 0.782 & 0.918 & 0.944 & 0.439 & 0.954 & 0.396 & 0.439 & Fickian \\
F-3 & 0.753 & 0.911 & 0.920 & 0.437 & 0.940 & 0.439 & 0.429 & Fickian \\
\hline
\end{tabular}




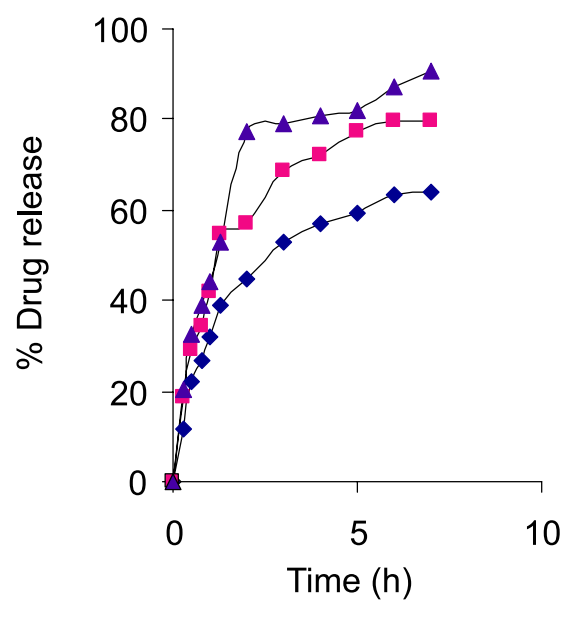

$\multimap \mathrm{F}-1 \quad \longrightarrow \mathrm{F}-2 \quad \longrightarrow \mathrm{F}-3$

FIGURE 1- Effect of Kollidon SR on the release of losartan potassium from the proposed formulations (Zero order kinetics)

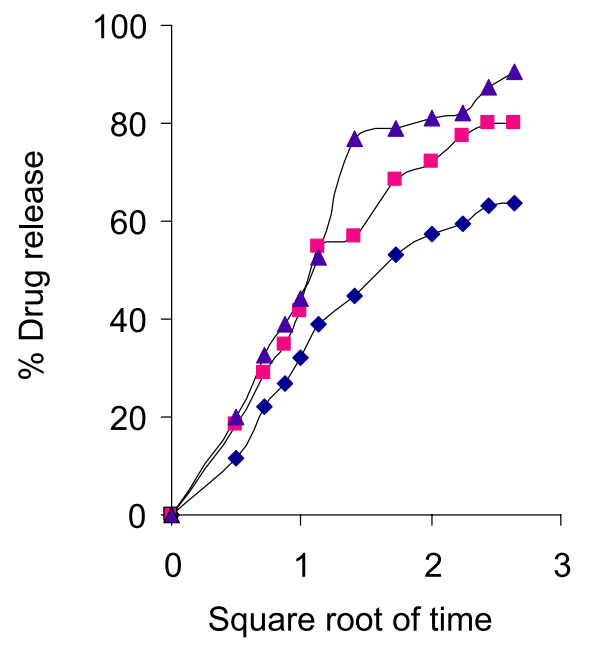

$\multimap \mathrm{F}-1 \quad \longrightarrow \mathrm{F}-2 \quad \longrightarrow \mathrm{F}-3$

FIGURE 2- Effect of Kollidon SR on the release of losartan potassium from the proposed formulations (Higuchi kinetics)

TABLE IV - Time required for $25 \%, 50 \%$, and $75 \%$ drug release and MDT values

\begin{tabular}{lcccc}
\hline Code & $\mathrm{t}_{25 \%}$ & $\mathrm{t}_{50 \%}$ & $\mathrm{t}_{75 \%}$ & MDT $(\mathrm{hr})$ \\
\hline F-1 & 0.66 & 3.29 & 7.93 & 3.44 \\
F-2 & 0.29 & 1.83 & 4.68 & 2.02 \\
F-3 & 0.21 & 1.40 & 3.64 & 1.61 \\
\hline
\end{tabular}

enhancement of $t_{75 \%}$ values from 3.64 to 7.93 (Table IV) indicating that the F-1 is the best formulation among the developed formulations. This finding indicates consider- able release retarding potentiality of the Kollidon SR that was also reported by previous work (Sakr, Alanazi, 2011). The relationship between release rate and polymer content is shown in Figure 3.

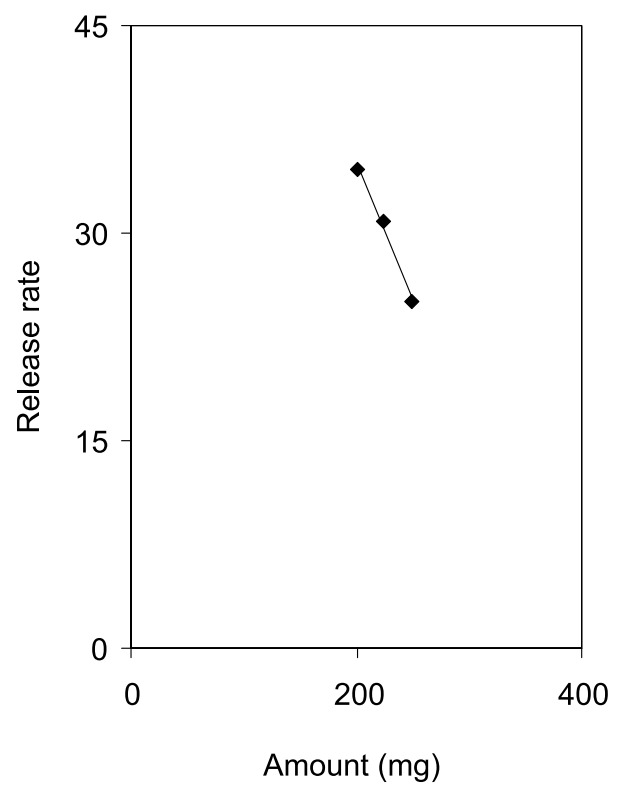

FIGURE 3- Effect of Kollidon SR on the release rate of losartan potassium.

\section{CONCLUSION}

The release rate of losartan potassium decreased with increase in polymer concentration. Therefore, it can be concluded that Kollidon SR is potential candidates for the development of sustained release losartan potassium matrix tablets. The best-proposed formulation F-1 may be used for the development of sustained release losartan potassium matrix tablet to meet the patient's demand for the management of hypertension.

\section{ACKNOWLEDGEMENTS}

The authors are thankful to Globe Pharmaceuticals Limited, Novo Healthcare Limited and BASF Limited, Bangladesh for their generous gift of the necessary ingredients.

\section{REFERENCES}

BONFILIO, R.; MENDONCA, T.F.; PEREIRA, G.R.; ARAUJO, M.B.; TARLEY, C.R.T.; Losartan potassium dissolution test for drug release evaluation in pharmaceutical capsules using HPLC and UV spectrophotometry. Quim. Nova, v.33, p.377-383, 2010. 
BOTZ, J.T.; CATHERINE, L.; BRADLY, B.J.; JEFFREY, O.; DON, S. Effects of slope and particle size on ant locomotion: Implications for choice of substrate by antlions. J. Kans. Entomol. Soc., v.76, p.426-435, 2003.

CHIEN, Y.W. Novel drug delivery systems. 2.ed. New York: Marcel Dekker, 1992. p.139-196.

CHITHALURU, K.; TADIKONDA, R.; GOLLAPUDI, R.; KANDULA, K.K.K. Formulation and invitro evaluation of sustained release matrix tablets of losartan potassium. Asian J. Pharm. Clin. Res., v.4, p.18-22, 2011.

CONSEA, C. Characterization of flow properties of powder coatings used in the automotive industry. Kona, v.22, p.94106, 2004.

COOPER, J.; GUNN, C. Tutorial pharmacy. 6.ed. New Delhi: CBS Publishers and Distributors, 1986. p.225.

GARCIA, R.A.; FLORES, R.A.; MAZENKO, C.E. Factors contributing to the poor bulk behavior of meat and bone meal and methods for improving these behaviors. Bioresour. Technol., v.98, p.2852-2858, 2007.

GREY, R.O.; BEDDOW, J.K. On the Hausner Ratio and its relationship to some properties of metal powders. Powder Technol., v.2, p.323-326, 1969.

HADJIIOANNOU, T.P.; CHRISTIAN, G.D.; KOUPPARIS, M.A. Quantitative calculation in pharmaceutical practice and research. 3.ed. New York: VCH Publishers, 1993. p.345-348.

HIGUCHI, T. Mechanism of sustained-action medication. Theoretical analysis of rate of release of solid drugs dispersed in solid matrices. J. Pharm. Sci., v.52, p.11451149, 1963.

KAUR, J.; SRINIVASAN, K.K.; JOSEPH, A.; GUPTA, A.; SINGH, Y.; SRINIVAS, K.S.; JAIN, G. Development and validation of stability indicating method for the quantitative determination of venlafaxine hydrochloride in extended release formulation using high performance liquid chromatography. J. Pharm. Bioallied Sci., v.2, p.2226, 2010.

KAUSHIK, D.; DUREJA, H.; SAINI, T.R. Formulation and evaluation of olanzapine mouth dissolving tablet by effervescent formulation approach. Indian Drugs, v.41, p.410-420, 2004.
KORSMEYER, R.W.; GUNNY, R.; DOCLER, E.; BURI, P.; PEPPAS, N.A. Mechanism of solute release from porous hydrophilic polymers. Int. J. Pharm., v.15, p.25-35, 1983.

LI, Q. Interparticle van der Waals force in powder flowability and compactibility. Int. J. Pharm., v.280, p.77-93, 2004.

MANSOOR, S.; SHARMA, R.; DHAKAL, S. Comparative in-vitro evaluation of commercially available pantroprazole tablets. Kathmandu Uni. Sci. Eng. Tech., v.1, p.1-7, 2007.

MOCKEL, J.E.; LIPPOLD, B.C. Zero order release from hydrocolloid matrices. Pharm. Res., v.10, p.1066-1070, 1993.

NELLORE, R.V.; REKHI, G.S.; HUSSAIN, A.S.; TILLMAN, L.G.; AUGSBRUGER, L.L. Development of metoprolol tartrate extended-release matrix tablet formulations for regulatory policy consideration. J. Control. Release, v.50, p.247-256, 1998.

PATEL, R.; BARIA, A. Formulation and process optimization of theophylline sustained release matrix tablet. Int. J. Pharm. Sci., v.1, p.230-242, 2009.

RASHID, H.O.; KABIR, A.K.L.; HOSSAIN, M.Z.; RAUF, A.S.S. Design and formulation of once daily naproxen sustained release tablet matrix from Methocel K 15M CR and Methocel K 100M CR. Iran. J. Pharm. Sci., v.5, p.215224, 2009.

RAWLINS, E.A. Bentley's text book of pharmaceutics. 5.ed. London: Cassell and Collier MacMillan, 1977. p.24-248.

REDDY, K. R.; MUTALIK, S.; REDDY, S. Once-daily sustained-release matrix tablets of nicorandil: formulation and in vitro evaluation. AAPS Pharm. Sci. Tech., v.4, p.480488, 2003.

REZA, M.S.; QUADIR, M.A; HAIDER, S.S. Comparative evaluation of plastic, hydrophobic and hydrophilic polymers as matrices for controlled release drug delivery. J. Pharm. Pharm. Sci., v.6, p.282-291, 2003.

ROUGH, S.L.; WILSON, D.I.; YORK, D.W. Effect of solids formulation on the manufacture of high shear mixer agglomerates. Adv. Powder Technol., v.16, p.145-169, 2005.

SAKR, W.; ALANAZI, F.; SAKR, A. Effect of kollidon SR on the release rate of albuterol sulphate from matrix tablets. Saudi Pharm. J., v.19, p.19-27, 2011. 
SHAH, D.; SHAH, Y.; RAMPRADHAN, M. Development and evaluation of controlled release diltiazem hydrochloride microparticles using cross-linked poly (vinyl alcohol). Drug Dev. Ind. Pharm., v.23, p.567-574, 1997.

S H A N M U G A M, S.; C H A K R A H A R I, R .; SUNDARAMOORTHY, K.; AYYAPPAN, T.; VETRICHELVAN, T. Formulation and evaluation of sustained release matrix tablets of losartan potassium. $J$. Pharm. Tech. Res., v.3, p.226-234, 2011.
SHATO, H.; MIYAGAWA, Y.; OKABE, T.; MIYAJIMA, M.; SUANADA, H. Dissolution mechanism of diclofenac sodium from wax matrix granules. J. Pharm. Sci., v.86, p.929-934, 1997.

Received for publication on $10^{\text {th }}$ July 2011 Accepted for publication on $13^{\text {th }}$ July 2012 